Article

\title{
Online Monitoring of a Long-Term Full-Scale Constructed Wetland for the Treatment of Winery Wastewater in Italy
}

\author{
Anacleto Rizzo *(1), Riccardo Bresciani, Nicola Martinuzzi and Fabio Masi \\ Iridra Srl, via La Marmora 51, 50121 Florence, Italy; bresciani@iridra.com (R.B.); martinuzzi@iridra.com (N.M.); \\ fmasi@iridra.com (F.M.) \\ * Correspondence: rizzo@iridra.com
}

Received: 23 December 2019; Accepted: 8 January 2020; Published: 12 January 2020

check for updates

Featured Application: Online monitoring by specific sensors can represent a reliable and essential component for smart information technologies (IT)-enhanced Constructed Wetland systems for industrial wastewater treatment.

\begin{abstract}
Nature-based solutions, such as Constructed Wetlands (CWs), for the treatment of industrial wastewater can be more efficiently operated making use of online monitored parameters as inlet/outlet flows and concentrations for specific substances. The present study compares different datasets acquired in a two-and-a-half-year-long period by normal laboratory methods and also from a specific $\mathrm{COD} / \mathrm{BOD}$ sensor installed at a winery CWs wastewater treatment plant in Tuscany, Italy. The CW wastewater treatment plant (WWTP) is composed of: equalization tank $\left(70 \mathrm{~m}^{3}\right)$; French Reed Bed $\left(1200 \mathrm{~m}^{2}\right)$; horizontal subsurface flow (HF) CW $\left(960 \mathrm{~m}^{2}\right)$ : free water system $\left(850 \mathrm{~m}^{2}\right)$; optional post-treatment sand filter $\left(50 \mathrm{~m}^{2}\right)$; and emergency recirculation. The obtained average performances for this last period are for COD 97.5\%, for MBAS 93.1\%, for N-NO2- $84.7 \%$, for NO3-39.9\%, and for TP $45.5 \%$. The online sensor has shown excellent performance in following the COD concentration patterns along the observed period. The qualitative and quantitative validity of the online sensor measurements has been assessed by statistical analysis ( $t$-test) and reported in the paper. Online data, acquired every $30 \mathrm{~min}$, availability is of extreme importance for the $\mathrm{CW}$ system performance optimization, for understanding the behavior of the WWTP in different operative scenarios, and finally for driving the powering on or off eventual process enhancement tools.
\end{abstract}

Keywords: constructed wetland; treatment wetland; hybrid; multistage system; French Reed Bed; winery wastewater; industrial wastewater; online monitoring; nature-based solution

\section{Introduction}

Constructed wetlands (CWs-also known as treatment wetlands) are nowadays recognized as reliable nature-based solutions not only for the treatment of domestic and municipal wastewater, but also for industrial wastewater. This is confirmed by numerous review works [1-3] and a book fully dedicated to the presentation of successful experiences in using CW for different kinds of wastewater [4].

Among the many industrial wastewater applications included in the review works, CWs for the treatment of winery wastewater seem to be one of the most promising and ready-to-the-market applications. Masi et al. [5] reviewed the topic in detail: (i) discussing the peculiarity of the winery wastewater and why CWs are suitable to treat it; (ii) reporting experiences from different countries and different types of CW technologies, from simple horizontal subsurface flow systems (HF) to multistage CWs, as well as a combination of both technological and nature-based solutions. Masi et al. [6] further 
investigated the topic, comparing three complex treatment schemes using different solutions to manage the high organic load driven by winery wastewater (nature-based French Reed Bed (FRB) in comparison with technological solutions, i.e., anaerobic and sequencing batch reactors) in order to identify the pros and cons of different approaches. Practical information for the application of CW for winery wastewater was also reported within the recent IWA book "Wetland Technology" [7].

In order to spread the use of CWs, one of the first "false myths" that was needed to be answered was their supposed short lifespan due to clogging issues. Despite that design guidelines to avoid clogging failures have been well-known among the CW designers since the early 90s, the monitoring of a successful full-scale CW wastewater treatment plant (WWTP) in the long-term period remains the best way to reply to these "false myths". Good examples come from the most diffused application of CWs, i.e., the treatment of domestic and municipal wastewater. For instance, Vymazal [8] reported the high treatment efficiencies of HF systems in the Czech Republic that were more than 20 years old. Other examples are available also for more innovative CW solutions, since FRBs have been shown to maintain high performances from 12 [9] up to 30 [10] years of functioning. The importance of reporting long-term performance of $\mathrm{CW}$ systems is starting to be considered also for other applications, such as agricultural runoff treatment [11]. On the other hand, long-term experiences of CW for industrial wastewater treatment are rare, also due to the relatively more recent application of $\mathrm{CW}$ to this field.

The capability to properly treat highly fluctuated influent loads is another useful point to increase the confidence in CW technology for industrial wastewater treatment. Although this peculiarity is well-known in the literature (e.g., [12]) and often reported in technical guidelines, it is usually based on single samples, and recent modeling studies are starting to request a better understanding of this feature [12-15]. In order to confirm the capability of CWs to face variable influent loads, online sensors can be useful tools. Although online sensors are nowadays available on the market, their use for monitoring CW treatment performance is a relatively novel research field. Few experiences are available in the peer review literature; this is probably linked to the common small-scale application of CWs. Garfı' et al. [16] tested the reliability and the economic feasibility of using online sensors, instead of manual samples, for monitoring CW performance on HF pilot plants. In order to set an operating protocol for obtaining reliable data, Papias et al. [17] studied the results from online monitoring of nitrogen compounds effluent from tertiary CWs in France (15,000 population equivalent (PE) WWTP). Corbella et al. [18] investigated the use of a microbial fuel cell as a low-cost sensor for CWs.

This work wants to contribute to the previously highlighted knowledge gaps as follows. Firstly, the works share the monitoring data from a full-scale $\mathrm{CW}$ serving a winery for more than 18 years of operation; the aim is to strengthen the idea that $\mathrm{CW}$ is a suitable technology also for the treatment of industrial wastewater in terms of long-term functioning. Secondly, the work also shows two and a half years of continuous monitoring data collected from an online COD sensor; to the best of our knowledge, this work is the first reporting an online monitoring of COD from a full-scale CW WWTP for secondary treatment, representing a good occasion to gain insights on the potentiality and the limitation of using online sensors for the monitoring of continuous CW performance.

\section{Materials and Methods}

\subsection{Case Study}

The case study is located in Castellina in Chianti (Siena, Italy; $43^{\circ} 25^{\prime} \mathrm{N}, 11^{\circ} 13^{\prime} \mathrm{E}$ ) and regards the Cecchi and Sons winery (hereinafter referred to as Cecchi winery). The winery performs only bottling and the aging of wine in cellar activities, since the wine is produced elsewhere. Therefore, the wastewater is produced from the washing of bottles, tanks, silos, grounds, and floors. This leads to a relatively constant wastewater production all over the year, with daily fluctuation linked to the variability of activities done during a working day in the winery.

The winery has been served by a CW WWTP since 2001. Masi et al. [5] described the background of the treatment plant, which had an upgrade in 2009 due to the doubling of winery production. 
Both the original and the upgraded versions of the CW WWTP were designed by the Italian firm IRIDRA. The upgraded CW WWTP, in operation since 2009, was designed to treat up to $100 \mathrm{~m}^{3} \mathrm{~d}^{-1}$ and $1900 \mathrm{PE}$ (referred to as organic load). The layout of the current CW treatment plant is (Figure 1): (i) equalization tank of $70 \mathrm{~m}^{3}$; (ii) FRB for raw wastewater at 1 st stage of $1200 \mathrm{~m}^{2}$; (iii) $\mathrm{HF}$ at 2nd stage of $960 \mathrm{~m}^{2}$; (iv) free water system (FWS) at 3rd stage of $850 \mathrm{~m}^{2}$; (v) optional post-treatment with a sand filter of $50 \mathrm{~m}^{2}$; and possibility for an emergency recirculation. The treated wastewater is discharged in a water body (Gena river).
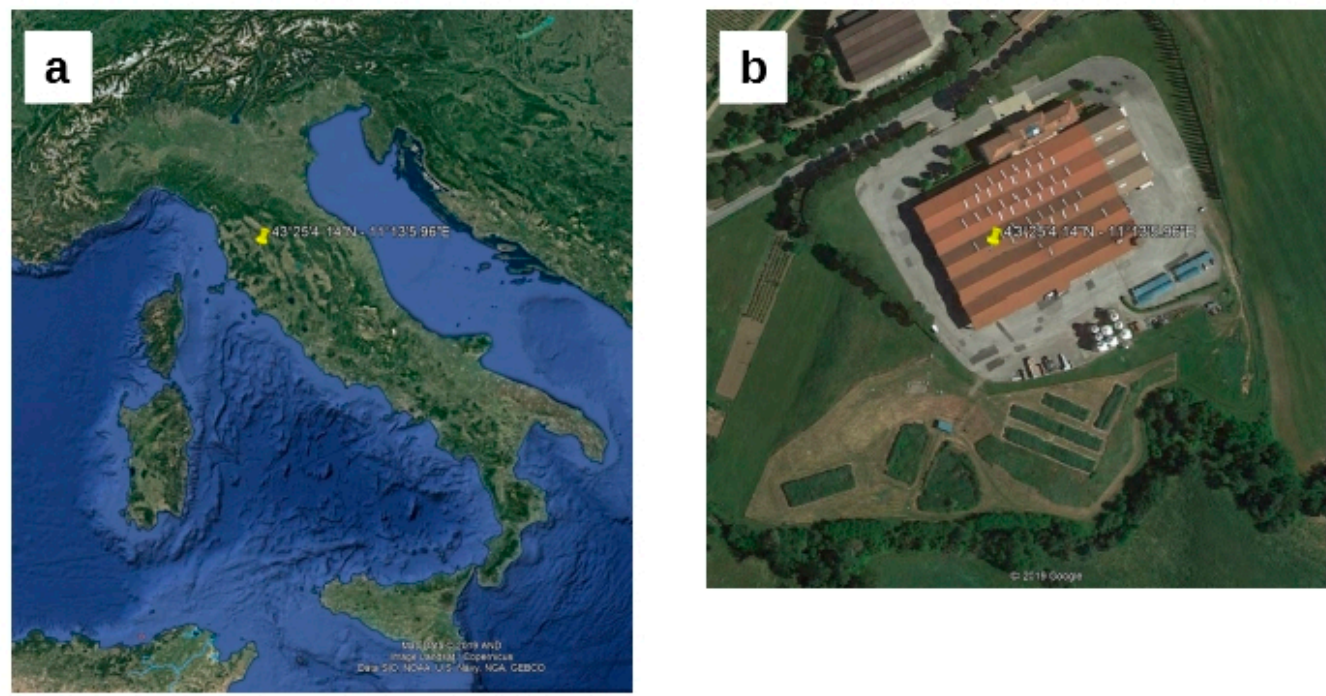

C
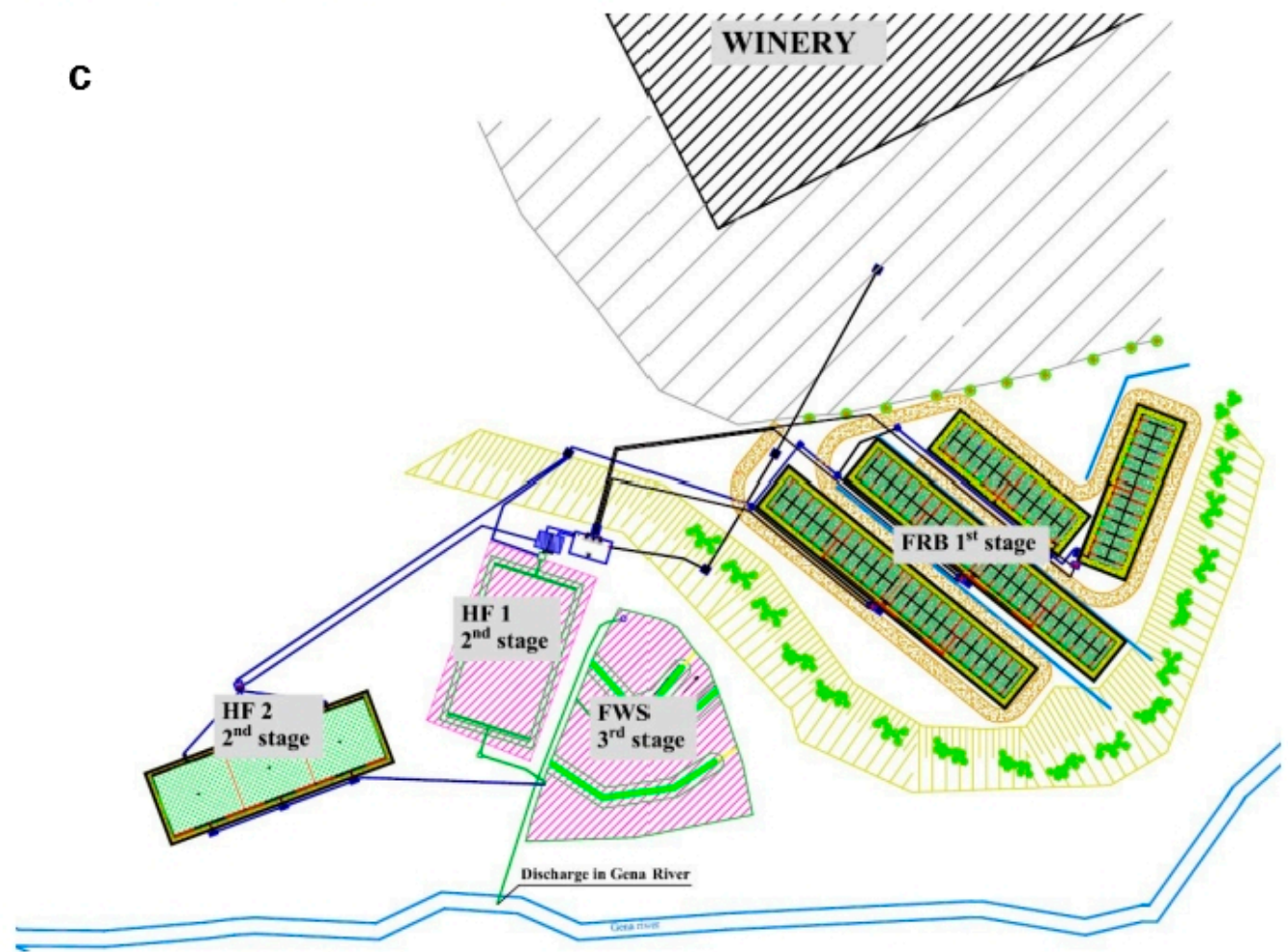

Figure 1. Constructed Wetlands (CW) wastewater treatment plant (WWTP) serving the Cecchi winery (Castellina in Chianti, Italy): (a) position; (b) aerial view; (c) planimetry, in which the stages in magenta represent the CW beds refurbished horizontal subsurface flow systems (HF) and recovered free water system (FWS) from the original CW WWTP of 2001. 
The FRB 1st stage was designed accordingly with recommendations gained from French experience [19]; the technical specifications are resumed in Table 1. A freeboard is present on the top of the FRB surface, to accumulate and mineralize the sludge (expected to be withdrawn every 20 years). The FRB 1st stage is composed of 3 lines ( $400 \mathrm{~m}^{2}$ each) divided into 4 beds to fit local orography. The FRB lines are loaded alternatively to maintain aerobic condition into the FRB beds, and mineralizing the organic layer retained on the surface. Each line is fed for a period of $3 \mathrm{~h}$, with a subsequent resting period of $6 \mathrm{~h}$ (in which the other lines start to be fed). The feeding of different line and the resting periods are regulated by an electric panel, which controls the activation of three pumps placed in the equalization tank. The lines are fed during the feeding period in batch: the daily volume to be treated is sent to the FRB line with different flushes (details are reported in Table 1) regulated by the electric panel; when the flush volume is reached, the FRB line has a resting period to properly infiltrate and treat the wastewater. Effluent of FRB 1st stage is sent by gravity to the HF 2nd stage. The FRB beds are planted with Phragmites australis.

Table 1. Technical specifications of the Cecchi CW WWTP: HF 1, refurbished bed from 2001 CW WWTP; HF 2, bed built during the 2009 upgrade.

\begin{tabular}{|c|c|c|c|c|c|c|}
\hline $\begin{array}{c}\text { 1st Stage French Reed } \\
\text { Beds }\end{array}$ & & & 2nd Stage HF CWs & HF 1 & HF 2 & \\
\hline $\mathrm{n}^{\circ}$ of FRB parallel line & 3 & & $\mathrm{n}^{\circ}$ of parallel sectors & 1 & 3 & \\
\hline Total surface area FRB & 1197 & $\mathrm{~m}^{2}$ & $\begin{array}{c}\text { Total surface area of HF } \\
\text { bed }\end{array}$ & 480 & 504 & $\mathrm{~m}^{2}$ \\
\hline $\begin{array}{l}\text { Surface area of each } \\
\text { FRB line }\end{array}$ & 399 & $\mathrm{~m}^{2}$ & $\begin{array}{l}\text { Surface area of each VF } \\
\text { line }\end{array}$ & 480 & 168 & $\mathrm{~m}^{2}$ \\
\hline $\begin{array}{l}\text { Feeding period per each } \\
\text { sector }\end{array}$ & 3 & $\mathrm{~h}$ & $\begin{array}{l}\text { Total height of the filter } \\
\text { media }\end{array}$ & \multicolumn{2}{|c|}{80} & $\mathrm{~cm}$ \\
\hline $\begin{array}{l}\text { Feeding resting period } \\
\text { per each sector }\end{array}$ & 6 & $\mathrm{~h}$ & Width of the HF sector & 16 & 14 & $\mathrm{~m}$ \\
\hline $\begin{array}{l}\text { Total height of the filter } \\
\text { media }\end{array}$ & 85 & $\mathrm{~cm}$ & Length of the HF sector & 16 & 12 & $\mathrm{~m}$ \\
\hline $\begin{array}{l}\text { FRB filter media layers } \\
\text { (from the bottom) }\end{array}$ & & & Bottom slope & \multicolumn{2}{|c|}{$1 \%$} & \\
\hline $\begin{array}{c}\text { Coarse gravel- } \varnothing \\
40 \mathrm{~mm}\end{array}$ & 25 & $\mathrm{~cm}$ & $\begin{array}{l}\text { Designed hydraulic } \\
\text { conductivity }\end{array}$ & \multicolumn{2}{|c|}{500} & $\mathrm{~m} / \mathrm{d}$ \\
\hline Gravel-Ø 5-20 mm & 20 & $\mathrm{~cm}$ & Designed porosity & \multicolumn{2}{|c|}{0.35} & \\
\hline Fine gravel—Ø 2-8 mm & 40 & $\mathrm{~cm}$ & $\begin{array}{l}\text { Designed minimum } \\
\text { hydraulic retention time }\end{array}$ & \multicolumn{2}{|c|}{2.4} & d \\
\hline Freeboard height & 50 & $\mathrm{~cm}$ & & & & \\
\hline $\begin{array}{c}\text { Minimum organic } \\
\text { loading rate }\left(70 \mathrm{~m}^{3} / \mathrm{d}\right)\end{array}$ & 160 & $\mathrm{~g}_{\mathrm{COD}} / \mathrm{m}^{2} / \mathrm{d}$ & & & & \\
\hline $\begin{array}{l}\text { Peak organic loading } \\
\text { rate }\left(100 \mathrm{~m}^{3} / \mathrm{d}\right)\end{array}$ & 230 & $\mathrm{~g}_{\mathrm{COD}} / \mathrm{m}^{2} / \mathrm{d}$ & & & & \\
\hline $\begin{array}{l}\text { Minimum Hydraulic } \\
\text { loading rate }\left(70 \mathrm{~m}^{3} / \mathrm{d}\right)\end{array}$ & 60 & $\mathrm{~L} / \mathrm{m}^{2} / \mathrm{d}$ & & & & \\
\hline $\begin{array}{l}\text { Peak Hydraulic loading } \\
\text { rate }\left(100 \mathrm{~m}^{3} / \mathrm{d}\right)\end{array}$ & 80 & $\mathrm{~L} / \mathrm{m}^{2} / \mathrm{d}$ & & & & \\
\hline $\begin{array}{l}\text { Batch feeding time } \\
\text { (maximum) }\end{array}$ & 16 & $\min$ & & & & \\
\hline Flush volume & 9.7 & $\mathrm{~m}^{3}$ & & & & \\
\hline HLR flush & 2.4 & $\mathrm{~cm}$ & & & & \\
\hline
\end{tabular}


The technical specifications of HF 2nd stage are resumed in Table 1. The HF 2nd stage was built realizing four parallel sectors. The first sector was placed in a single bed and has a surface of $480 \mathrm{~m}^{2}$; it was realized when refurbishing the HF bed of the CW WWTP of 2001 (hereinafter referred to as HF 1). The other 3 parallel HF sectors were realized in a single bed (hereinafter referred to as HF 2), hydraulically separated into three sectors. The sectors were designed with a length-to-width ratio proximal to 1:1 to limit the clogging risk at the cross-sectional area. Effluent of HF 2nd stage is sent by gravity to the FWS 3rd stage. The HF beds are planted with Phragmites australis.

The FWS 3rd stage was recovered from the CW WWTP of 2001 and has a total surface area of $850 \mathrm{~m}^{2}$. The FWS 3rd stage was designed with five cells in series. The first four FWS cells have an average water depth of $0.4 \mathrm{~m}$, while the last FWS cell has an average depth of $1.0 \mathrm{~m}$. The designed hydraulic retention time of the FWS is 3.3 days with an influent hydraulic load of $100 \mathrm{~m}^{3} / \mathrm{d}$. Variable water depth was designed in each cell in order to place different autochthonous aquatic plants (Typha latifolia, Myriophyllum spicatum, Phragmites australis, Elodea Canadensis, Ceratophyllum demersum, Lythrum salicaria, Iris pseudacorus, Epilobium hirsutum, Alisma plantago aquatica, and Butumus umbellatus). Effluent from the FWS 3rd stage can be either sent the optional sand filer with a pumping system or discharged by gravity in the Gena river.

The CW WWTP was designed to respect the water quality targets fixed by the Italian legislation for the discharge of industrial wastewater in water body: $\mathrm{pH} 5.5-9.5$; COD $160 \mathrm{mg} \mathrm{L}^{-1}$; $\mathrm{BOD}_{5} 40 \mathrm{mg} \mathrm{L}^{-1}$; $\mathrm{N}-\mathrm{NH} 4+15 \mathrm{mg} \mathrm{L}^{-1}$; TSS $80 \mathrm{mg} \mathrm{L}^{-1}$; TP $10 \mathrm{mg} \mathrm{L}^{-1}$; N-NO2- $0.6 \mathrm{mg} \mathrm{L}^{-1}$; N-NO3- $20 \mathrm{mg} \mathrm{L}^{-1}$; MBAS $2.0 \mathrm{mg} \mathrm{L}^{-1}$.

\subsection{Dataset and Statistical Analyses}

The water quality dataset comes from the Cecchi winery, which has a strict internal monitoring procedure to check the performance of the CW WWTP. Grab samples were taken every month from influent and effluent of each CW stage. The water quality data here presented were also implemented with the samples taken by the Regional Authority for discharge control (ARPAT), which collected effluent grab samples with a frequency of 3-4 samples per year. Water quantity was also monitored by the Cecchi winery, recoding the cumulated water volume discharged by the CW WWTP once per month.

The water quality dataset here presented regards the data collected from almost two and a half years, from January 2017 to June 2019; therefore, the data reports the functioning of the CW WWTP from 8 to 10 and a half years after the upgrade. These data are different from those presented by Masi et al. [5], which corresponded to 13 years of functioning (up to 2014), including the pre-upgrade

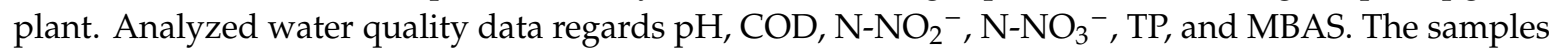
taken by Cecchi winery for internal monitoring were analyzed in an internal chemistry laboratory of the Cecchi winery, using a spectrophotometer and following the ISO international standards and methods. External samples from ARPAT were analyzed by a certified laboratory, according to standard methods [20].

The dataset was used to calculate mean, standard deviation, minimum, and maximum values for each pollutant parameter at different stages of the CW of Cecchi winery: influent (IN); effluent from the 1st stage FRB beds (OUT FRB); effluent from the 2nd stage refurbished HF bed (out HF 1); effluent from the 2nd stage HF beds built during the 2009 upgrade (OUT HF 2); effluent from the 3rd stage FWS bed (OUT FWS); effluent from the official effluent sampling point, after the optional sand filter (OUT fin). Each monitored pollutant had more than 10 samples; therefore, $t$-tests were used to test the significance of differences of mean values. An unpaired $t$-test with one-tail distribution was used to check if the effluent concentrations were significantly lower than influent concentrations; this test was separately performed among all the CW WWTP stages. Moreover, an unpaired $t$-test with two-tail distribution was used to test if the effluent HF 1 and HF 2 concentrations were significantly different among each other. The statistical analyses were done with Microsoft Excel. 
Since 2017, the Cecchi winery decided to implement the monitoring of the CW WWTP with a COD online sensor (Hach Lange-UVAS plus) based on ultraviolet absorbance. The online sensor was installed to monitor the final effluent (time span of $30 \mathrm{~min}$ ). The online sensor received ordinary maintenance every year from specialized personnel and it was checked every three months by the Cecchi winery. The internal check procedure consisted of comparing the COD concentration measured by the online sensor with results from grab samples analyzed by an external certified laboratory. In case of a significant difference between the two measures, the COD sensor was re-calibrated. The COD concentration measured by the online sensor is here compared with the water quality dataset for the whole two-and-a-half-year monitored period.

\section{Results}

\subsection{Overall CW WWTP Functioning and Performance}

The monthly volume discharged by the CW WWTP is represented in Figure 2. Neglecting the evapotranspiration and the precipitation, the effluent volume can be considered a suitable measure to make some consideration on influent hydraulic loads. To this regards, it must be noted that the monthly pattern of effluent discharge can be also affected by the precipitation pattern; therefore, consideration on winery wastewater production based on data exposed in Figure 2 must be taken only as indicative of real influent hydraulic loads faced by the CW WWTP in the monitoring period. Averaging the monthly volume, the daily treated flow was $60.5 \pm 28.3 \mathrm{~m}^{3} \mathrm{~d}^{-1}$ during the monitoring period, with the maximum value equal to $118.4 \mathrm{~m}^{3} \mathrm{~d}^{-1}$. Therefore, the CW WWTP worked within the range of hydraulic loads sets in the design phase, which assumed an influent flow rate variable from 70 to $100 \mathrm{~m}^{3} \mathrm{~d}^{-1}$ function of a different scenario of winery production. As expected, the wastewater production is quite stable among the different months, with a significant monthly variability only in summer months.

\section{Effluent discharge}

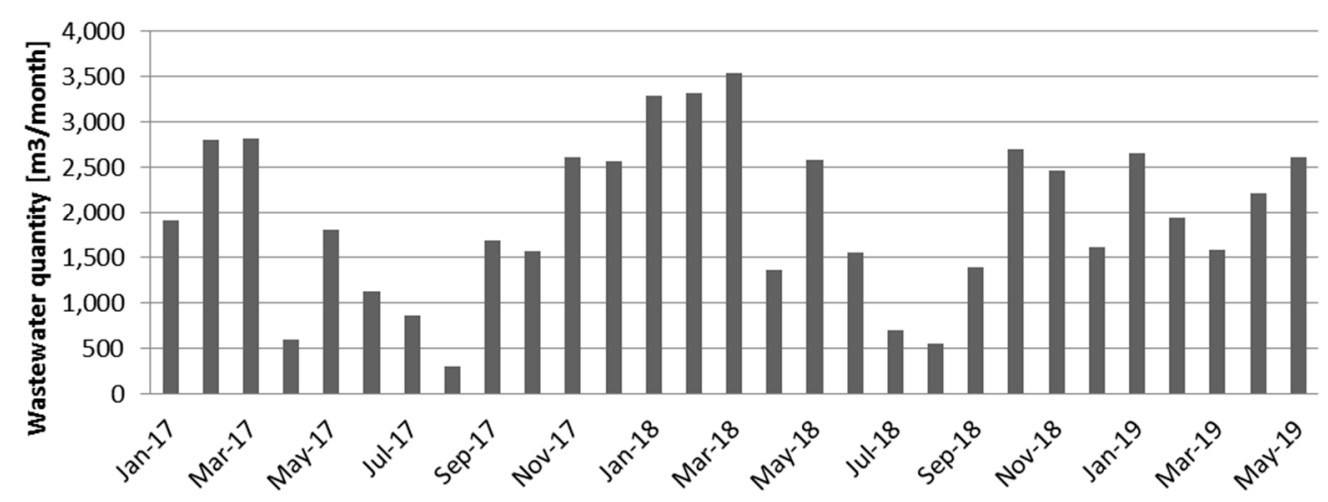

Figure 2. Monthly effluent discharge from the CW of Cecchi winery, monitored from January 2017 to May 2019.

The results of the statistical analysis on the pollutant parameters are graphically represented by the Box-Whisker plots of Figure 3, while the numerical results are reported in Table 2. Mean removal efficiencies and the results of the $t$-tests are resumed in Table 3 . The effluent water quality limits were respected for all the monitored pollutants throughout the studied period. This confirms the high overall performance of the CW WWTP. Referring to mean concentrations, the mean removal efficiencies during the monitoring period were $97.5 \%$, $45.5 \%, 84.7 \%, 39.9 \%$, and $93.1 \%$ for COD, TP, N-NO2-, N-NO3-, and MBAS, respectively, all significantly different according to the $t$-test (Table 3).

The FRB 1st stage already provided a very efficient and statistically significant removal of COD (mean removal 70.2\%) and MBAS (73.4\%), as clearly visible from Figure 3. Statistically significant differences were registered for all the stages in terms of COD and MBAS (see Figure 3 and Table 3). 
This is particularly relevant for the COD parameter; indeed, the high removal efficiencies of the FRB 1st stage would not be enough to respect the water quality standard (mean COD concentration OUT FRB, $345 \mathrm{mg} \mathrm{L}^{-1}$ ), leading HF 2nd (mean COD concentration OUT HF, $95 \mathrm{mg} \mathrm{L}^{-1}$ ), and FWS 3rd (mean COD concentration, OUT FWS $57 \mathrm{mg} \mathrm{L}^{-1}$ ) stages to play a fundamental role in making the CW WWTP effluent suitable for discharge in water body in terms of COD pollutant. The Box-Whisker plot of Figure 3 also evidences the capability of $\mathrm{CW}$ to smooth the influent organic load variability, as clear by observing the very high variability of COD concentration in the influent.
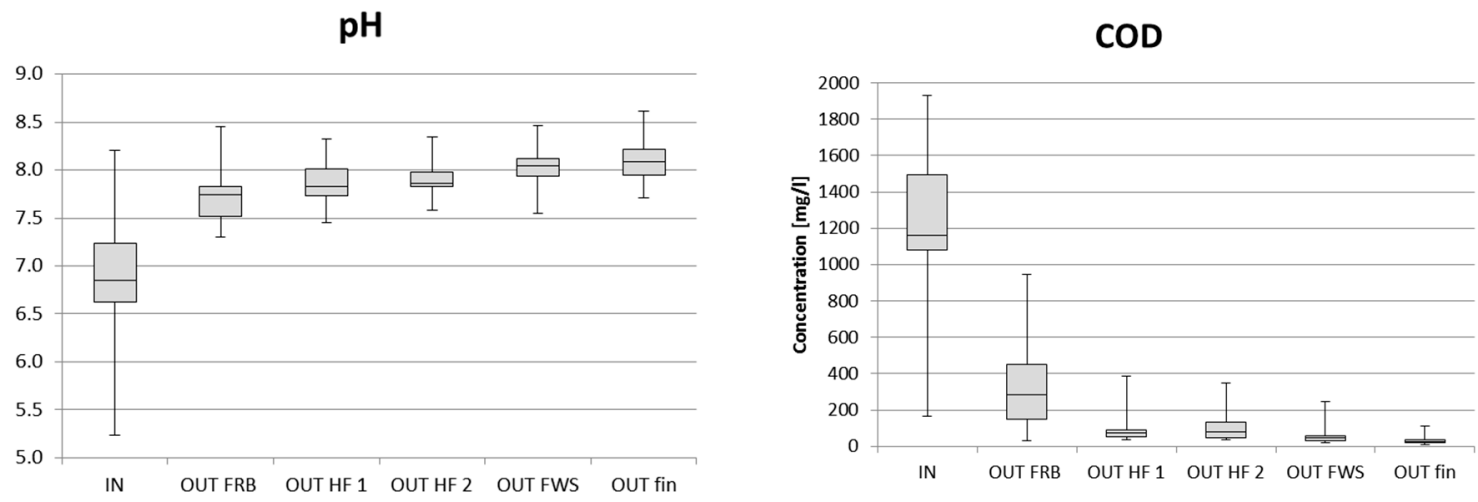

N-NO2-

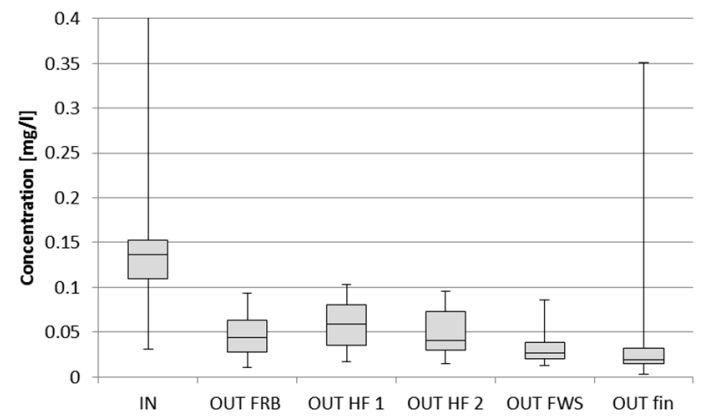

N-NO3-

TP

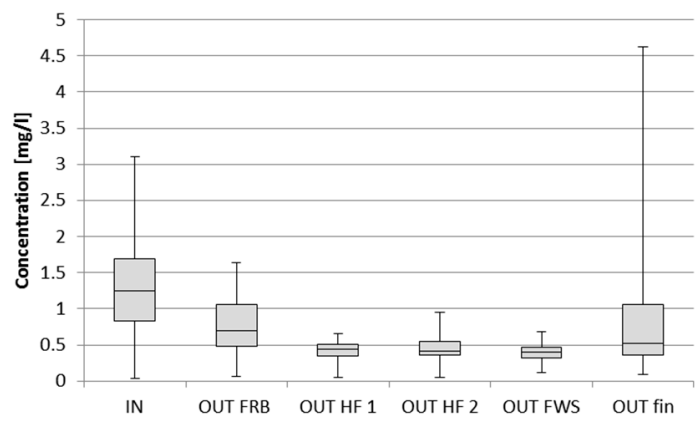

Anionic Surfactants (MBAS)
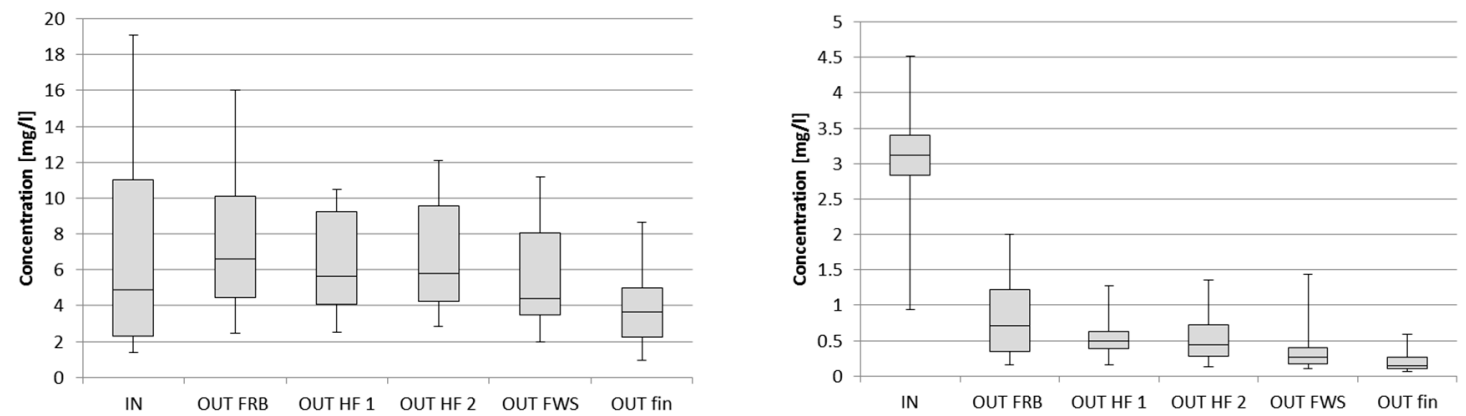

Figure 3. Box-Whisker plots for $\mathrm{pH}, \mathrm{COD}, \mathrm{N}-\mathrm{NO} 2-, \mathrm{N}-\mathrm{NO} 3-, \mathrm{TP}$, and anionic surfactants (MBAS) at the different stages of the CW of Cecchi winery: influent (IN); effluent from the 1st stage French Reed Bed (FRB) beds (OUT FRB); effluent from the 2nd stage refurbished HF bed (out HF 1); effluent from the 2nd stage HF beds built during the 2009 upgrade (OUT HF 2); effluent from the 3rd stage FWS bed (OUT FWS); effluent from the official effluent sampling point, after the optional sand filter (OUT fin). Data from 19 January 2017 to 14 June 2019. 
Table 2. Statistical analysis of pollutant concentrations of wastewater treated by the CW of Cecchi winery at the different stages of the $\mathrm{CW}$ of Cecchi winery: influent (IN); effluent from the 1st stage FRB beds (OUT FRB); effluent from the 2nd stage refurbished HF bed (out HF 1); effluent from the 2nd stage HF beds built during the 2009 upgrade (OUT HF 2); effluent from the 3rd stage FWS bed (OUT FWS); effluent from the official effluent sampling point, after the optional sand filter (OUT fin). Data from 19 January 2017 to 14 June 2019.

\begin{tabular}{|c|c|c|c|c|c|c|c|}
\hline & & IN & OUT FRB & OUT HF 1 & OUT HF 2 & OUT FWS & OUT Fin \\
\hline \multirow[t]{7}{*}{$\mathrm{pH}$} & Mean & 6.8 & 7.7 & 7.9 & 7.9 & 8.0 & 8.1 \\
\hline & Std. dev. & 0.6 & 0.3 & 0.2 & 0.2 & 0.2 & 0.2 \\
\hline & Min & 5.2 & 7.3 & 7.5 & 7.6 & 7.6 & 7.7 \\
\hline & $\operatorname{Max}$ & 8.2 & 8.5 & 8.3 & 8.3 & 8.5 & 8.6 \\
\hline & $80^{\circ}$ perc. & 7.3 & 7.9 & 8.0 & 8.0 & 8.2 & 8.3 \\
\hline & No. of s. & 29 & 29 & 28 & 28 & 29 & 38 \\
\hline & Discharge limit & & & & & & $5.5-9.5$ \\
\hline \multirow{7}{*}{$\begin{array}{c}\mathrm{COD} \\
{\left[\mathrm{mg} \mathrm{L}^{-1}\right]}\end{array}$} & Mean & 1159 & 345 & 84.0 & 105.9 & 57.1 & 29.0 \\
\hline & Std. dev. & 432 & 273 & 66.1 & 83.0 & 45.4 & 19.2 \\
\hline & Min & 166 & 30 & 34.6 & 34.5 & 20.5 & 8.9 \\
\hline & $\operatorname{Max}$ & 1930 & 948 & 387.0 & 347.0 & 249.0 & 114.0 \\
\hline & $80^{\circ}$ perc. & 1530 & 509 & 94.3 & 143.0 & 70.8 & 37.9 \\
\hline & No. of s. & 29 & 29 & 28 & 28 & 29 & 37 \\
\hline & Discharge limit & & & & & & 160 \\
\hline \multirow{7}{*}{$\begin{array}{l}\text { N-NO2- } \\
{\left[\mathrm{mg} \mathrm{L}^{-1}\right]}\end{array}$} & Mean & 0.24 & 0.05 & 0.06 & 0.05 & 0.03 & 0.04 \\
\hline & Std. dev. & 0.63 & 0.02 & 0.03 & 0.02 & 0.02 & 0.06 \\
\hline & Min & 0.03 & 0.01 & 0.02 & 0.02 & 0.01 & 0.00 \\
\hline & $\operatorname{Max}$ & 3.50 & 0.09 & 0.10 & 0.10 & 0.09 & 0.35 \\
\hline & $80^{\circ}$ perc. & 0.16 & 0.07 & 0.08 & 0.07 & 0.04 & 0.04 \\
\hline & No. of s. & 29 & 29 & 28 & 28 & 29 & 38 \\
\hline & Discharge limit & & & & & & 0.6 \\
\hline \multirow{7}{*}{$\begin{array}{l}\text { N-NO3- } \\
{\left[\mathrm{mg} \mathrm{L}^{-1}\right]}\end{array}$} & Mean & 1.3 & 0.8 & 0.4 & 0.5 & 0.4 & 0.8 \\
\hline & Std. dev. & 0.7 & 0.4 & 0.1 & 0.2 & 0.1 & 0.8 \\
\hline & Min & 0.0 & 0.1 & 0.1 & 0.1 & 0.1 & 0.1 \\
\hline & Max & 3.1 & 1.6 & 0.7 & 1.0 & 0.7 & 4.6 \\
\hline & $80^{\circ}$ perc. & 1.8 & 1.2 & 0.6 & 0.6 & 0.5 & 1.1 \\
\hline & No. of s. & 29 & 29 & 28 & 28 & 29 & 38 \\
\hline & Discharge limit & & & & & & 20 \\
\hline \multirow{7}{*}{$\begin{array}{c}\mathrm{TP} \\
{\left[\mathrm{mg} \mathrm{L}^{-1}\right]}\end{array}$} & Mean & 7.2 & 7.5 & 6.4 & 6.7 & 5.6 & 3.9 \\
\hline & Std. dev. & 5.6 & 3.8 & 2.6 & 2.9 & 2.5 & 2.1 \\
\hline & Min & 1.4 & 2.4 & 2.5 & 2.8 & 2.0 & 0.9 \\
\hline & Max & 19.1 & 16.0 & 10.5 & 12.1 & 11.2 & 8.6 \\
\hline & $80^{\circ}$ perc. & 12.1 & 11.0 & 9.4 & 10.0 & 8.6 & 5.2 \\
\hline & No. of s. & 29 & 29 & 28 & 28 & 29 & 38 \\
\hline & Discharge limit & & & & & & 10 \\
\hline \multirow{7}{*}{$\begin{array}{c}\text { MBAS } \\
{\left[\mathrm{mg} \mathrm{L}^{-1}\right]}\end{array}$} & Mean & 3.0 & 0.8 & 0.5 & 0.5 & 0.4 & 0.2 \\
\hline & Std. dev. & 0.7 & 0.5 & 0.2 & 0.3 & 0.3 & 0.1 \\
\hline & Min & 0.9 & 0.2 & 0.2 & 0.1 & 0.1 & 0.1 \\
\hline & Max & 4.5 & 2.0 & 1.3 & 1.4 & 1.4 & 0.6 \\
\hline & $80^{\circ}$ perc. & 3.5 & 1.3 & 0.7 & 0.8 & 0.5 & 0.3 \\
\hline & No. of s. & 29 & 29 & 28 & 28 & 29 & 38 \\
\hline & Discharge limit & & & & & & $2 *$ \\
\hline
\end{tabular}

${ }^{*}$ Expressed in terms of total surfactants. 
Table 3. Results of $t$-test (expressed in percentage and italics) and removal efficiencies (absolute in comparison to influent wastewater and relative among the stages) of the $\mathrm{CW}$ of Cecchi winery: influent (IN); effluent from the 1st stage FRB beds (OUT FRB); effluent from the 2nd stage refurbished HF bed (out HF 1); effluent from the 2nd stage HF beds built during the 2009 upgrade (OUT HF 2); effluent from the 3rd stage FWS bed (OUT FWS); effluent from the official effluent sampling point, after the optional sand filter (OUT fin). Data from 19 January 2017 to 14 June 2019. Statistically significant results $(<5 \%)$ are evidenced by a gray background cell. Results of the overall CW WWTP are reported in bold.

\begin{tabular}{|c|c|c|c|c|c|c|c|}
\hline Pollutant & & $\begin{array}{c}\text { IN-OUT } \\
\text { FRB }\end{array}$ & $\begin{array}{c}\text { OUT HF } \\
\text { 1-OUT } \\
\text { HF } 2\end{array}$ & $\begin{array}{c}\text { OUT } \\
\text { FRB-OUT } \\
\text { HF } 1\end{array}$ & $\begin{array}{l}\text { OUT HF } \\
\text { 1-OUT } \\
\text { FWS }\end{array}$ & $\begin{array}{c}\text { OUT } \\
\text { FWS-OUT } \\
\text { Fin }\end{array}$ & $\underset{\text { Fin }}{\text { IN-OUT }}$ \\
\hline $\mathrm{pH}$ & $t$ value & $<0.01 \%$ & $39.68 \%$ & $5.02 \%$ & $0.05 \%$ & $9.10 \%$ & $<0.01 \%$ \\
\hline \multirow[t]{3}{*}{ COD } & \multirow{3}{*}{$\begin{array}{l}t \text { value } \\
\text { Relative } \\
\text { rem. eff. } \\
\text { Absolute } \\
\text { rem. eff. }\end{array}$} & $<0.01 \%$ & \multirow[t]{3}{*}{$27.99 \%$} & $<0.01 \%$ & $4.01 \%$ & $0.17 \%$ & $<0.01 \%$ \\
\hline & & $70.23 \%$ & & $72.46 \%$ & $50.09 \%$ & $49.27 \%$ & \\
\hline & & $70.23 \%$ & & $21.57 \%$ & $3.05 \%$ & $2.43 \%$ & $97.50 \%$ \\
\hline \multirow[t]{2}{*}{$\mathrm{TP}$} & \multirow{2}{*}{$\begin{array}{l}t \text { value } \\
\text { Absolute } \\
\text { rem. eff. }\end{array}$} & $42.18 \%$ & \multirow[t]{2}{*}{$66.14 \%$} & \multirow[t]{2}{*}{$10.76 \%$} & \multirow[t]{2}{*}{$12.80 \%$} & $0.28 \%$ & $0.25 \%$ \\
\hline & & & & & & & $45.55 \%$ \\
\hline \multirow[t]{2}{*}{ N-NO2- } & \multirow{2}{*}{$\begin{array}{l}t \text { value } \\
\text { Absolute } \\
\text { rem. eff. }\end{array}$} & $5.13 \%$ & \multirow[t]{2}{*}{$18.08 \%$} & \multirow[t]{2}{*}{$4.43 \%$} & \multirow[t]{2}{*}{$<0.01 \%$} & \multirow[t]{2}{*}{$32.15 \%$} & $4.41 \%$ \\
\hline & & & & & & & $84.65 \%$ \\
\hline \multirow[t]{3}{*}{ N-NO3- } & \multirow{3}{*}{$\begin{array}{l}t \text { value } \\
\text { Relative } \\
\text { rem. eff. } \\
\text { Absolute } \\
\text { rem. eff. }\end{array}$} & $0.04 \%$ & \multirow[t]{3}{*}{$50.30 \%$} & $0.01 \%$ & \multirow[t]{3}{*}{$18.82 \%$} & $0.32 \%$ & $0.32 \%$ \\
\hline & & $40.45 \%$ & & $43.71 \%$ & & $-100.19 \%$ & $39.94 \%$ \\
\hline & & $40.45 \%$ & & $26.03 \%$ & & $-30.06 \%$ & \\
\hline \multirow[t]{3}{*}{ MBAS } & $t$ value & $<0.01 \%$ & \multirow[t]{3}{*}{$65.44 \%$} & $0.68 \%$ & $1.14 \%$ & $0.73 \%$ & $<0.01 \%$ \\
\hline & $\begin{array}{l}\text { Relative } \\
\text { rem. eff. }\end{array}$ & $73.45 \%$ & & $36.15 \%$ & $11.77 \%$ & $42.09 \%$ & \\
\hline & $\begin{array}{l}\text { Absolute } \\
\text { rem. eff. }\end{array}$ & $73.45 \%$ & & $9.60 \%$ & $1.73 \%$ & $5.01 \%$ & $93.11 \%$ \\
\hline
\end{tabular}

Despite that statistically significant differences are evident only from IN to OUT, the $\mathrm{pH}$ Box-Whisker plot suggests a constant basification of treated wastewater among the different stages. The mean influent $\mathrm{pH}$ passes from an influent value of 6.8 to 8.1 in the effluent (mean values). By the way, the effluent $\mathrm{pH}$ never exceeded the limit value for discharge (9.5).

The role of the different stages is less evident in terms of total phosphorous. Indeed, a statistically significant difference is registered only for the whole CW WWTP, as visible in Figure 3 and Table 3. On the other hand, the whole system successfully worked as a buffer and a sink of TP, helping to respect the limit for discharge. Although the mean influent TP concentration $\left(7.2 \mathrm{mg} \mathrm{L}^{-1}\right)$ is already below the limit value $\left(10 \mathrm{mg} \mathrm{L}^{-1}\right)$, the influent TP concentrations are showing several peaks above this value (up to a maximum measured value of $19.1 \mathrm{mg} \mathrm{L}^{-1}$ ), leading the CW WWTP to be fundamental to respect the Italian legislation for discharge. Other monitored nutrient pollutants, i.e., N-NO2- and $\mathrm{N}-\mathrm{NO} 3-$, resulted less problematic, since their influent values were always below the target values (0.6 $\mathrm{mg} \mathrm{L}^{-1}$ and $20 \mathrm{mg} \mathrm{L}^{-1}$, respectively).

\subsection{Online COD Sensor}

The temporal series of influent and effluent COD concentrations are reported in Figure 4, together with the COD effluent concentration registered by the online sensor every $30 \mathrm{~min}$ for almost all the whole monitored period. As visible from Figure 4, the online sensor gave excellent results in following the increasing and decreasing patterns of effluent COD concentration. For instance, the online sensor properly measured the sharp increase (but still far below the effluent COD water quality target of $160 \mathrm{mg} \mathrm{L}^{-1}$ ) of effluent COD concentration observed from November 2017 to December 2017. Similarly, 
the subsequent slight decreasing pattern until June 2018 was properly caught. The maintenance procedure also guaranteed good performance in time as visible, for instance, by the proper measurement of a slight increase of COD concentration from June 2019 to July 2019.

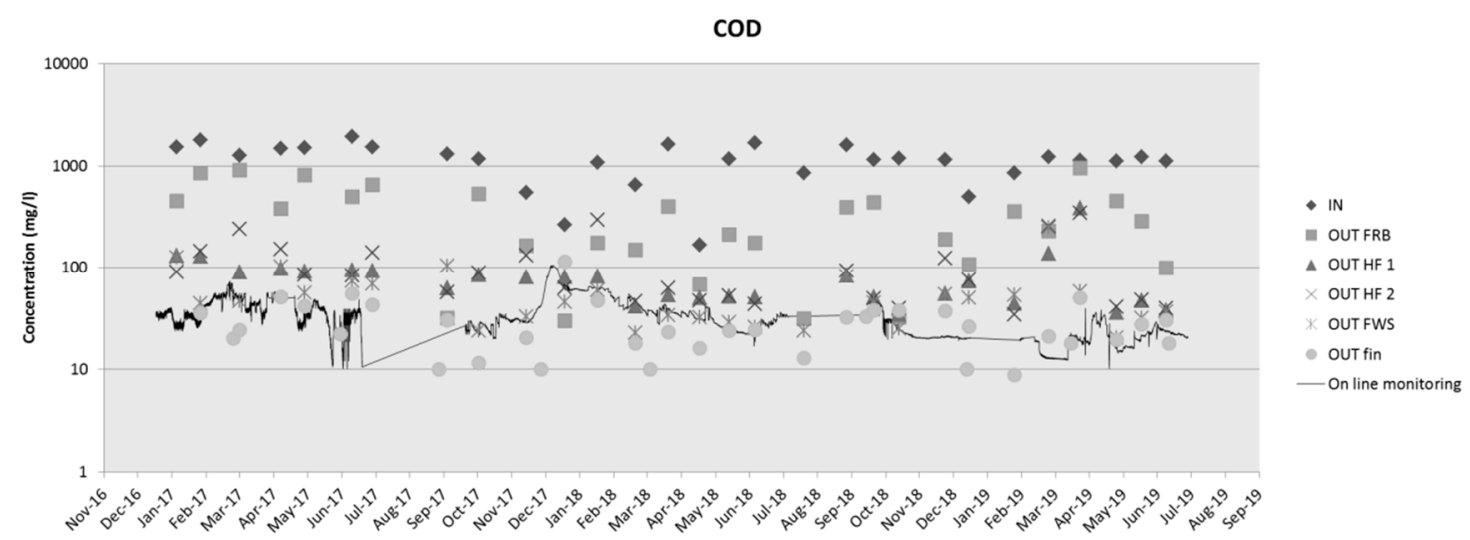

Figure 4. Samples and online sensors results for the COD monitoring of the CW of Cecchi winery. Monitored samples were taken from 19 January 2017 to 14 June 2019 at the different stages of the CW of Cecchi winery: influent (IN); effluent from the 1st stage FRB beds (OUT FRB); effluent from the 2nd stage refurbished HF bed (out HF 1); effluent from the 2nd stage HF beds built during the 2009 upgrade (OUT HF 2); effluent from the 3rd stage FWS bed (OUT FWS); effluent from the official effluent sampling point, after the optional sand filter (OUT fin). The online sensor monitored the final effluent, i.e., OUT fin, throughout the sampled period with a time span of $30 \mathrm{~min}$; missing data from the online sensor are filled with a linear interpolated line.

The qualitative goodness of the online sensor measurement is also confirmed by the analysis of errors between the sampled COD effluent concentration and the daily mean COD effluent concentration monitored by the online sensor. On the 26 samples available for direct comparison, the error range was $-160 \%-+60 \%$, with a mean error of $-17 \% \pm+62 \%$. More relevant, $73 \%$ of the samples fallen within the error range $-50 \%-+50 \%$ (Figure 5 ). It must be noted that the monitored effluent concentration was very low, with a mean value of $29 \pm 19 \mathrm{mg} \mathrm{L}^{-1}$, i.e., often near the bottom measurable threshold for COD measurement $\left(10 \mathrm{mg} \mathrm{L}^{-1}\right)$. On the other hand, the frequency density function of the errors (Figure 5) evidences a more frequent underestimation of effluent concentrations.

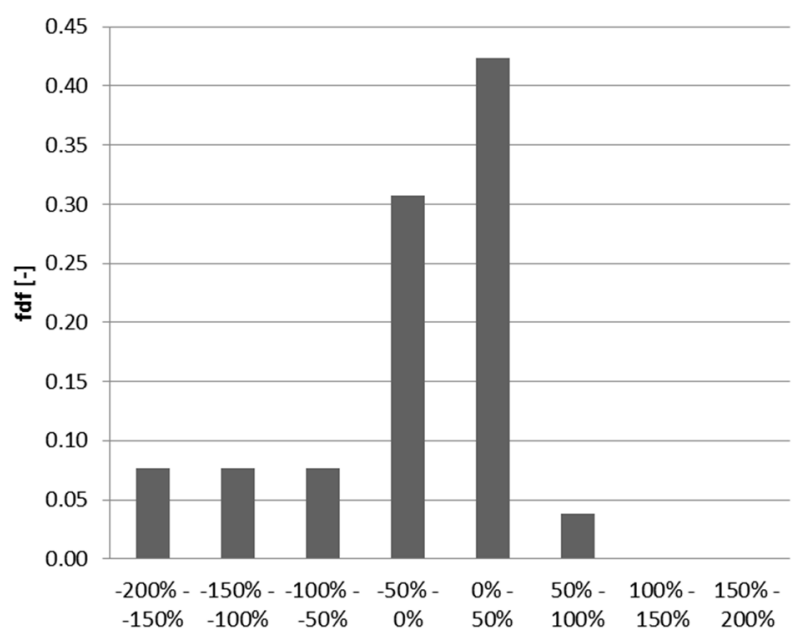

Figure 5. Relative frequency density function of the error between the sampled COD effluent concentration and the daily mean COD effluent concentration monitored by the online sensor. Data from 9 February 2017 to 14 June 2019. 


\section{Discussion and Conclusions}

The CW WWTP of Cecchi winery fully respected the limit for discharge for the whole monitored period (two and a half monitoring years), not only confirming in general [1-7], but evidencing the suitability in long-term (up to 10 and a half years after upgrade, 18 and a half years including upgraded plant) of CW technology for the treatment of winery wastewater. For the last two and a half years, the efficiency of the CW WWTP is also demonstrated continuously with a sampling rate of half an hour for all the days. A similar monitoring campaign is quite unique in the Constructed Wetlands sector and in the available published literature.

This work further evidenced the suitability of the FRB as 1st for the treatment of winery wastewater. The mean COD removal efficiency observed from the FRB 1st stage of the Cecchi CW WWTP was 70\%, slightly lower but in agreement with the range registered from several FRB 1st stage for domestic and municipal wastewater in France. Morvannou et al. [10] report an average COD removal efficiency of the FRB 1st stage of $77 \% \pm 2 \%$ from 250 monitored CW WWTPs (oldest 30 years old), while Paing et al. [9] refer to a mean COD removal efficiency of $80 \% \pm 13 \%$ from 169 monitored CW WWTPs (oldest 12 years old). The proper functioning of the FRB 1st stage can be attributed to a correct load in terms of the organic loading rate (OLR). Indeed, the Cecchi CW WWTP was loaded with a mean OLR of $62 \pm 33 \mathrm{~g}_{\mathrm{COD}} \mathrm{m}^{-2} \mathrm{~d}^{-1}$ (range 8-145 $\mathrm{g}_{\mathrm{COD}} \mathrm{m}^{-2} \mathrm{~d}^{-1}$ ), in agreement with value reported from previous monitored periods $[5,6]$. Therefore, the FRB 1st stage of the Cecchi CW WWTP worked with sufficiently conservative OLRs, since FRB 1st stages are usually designed with an OLR of about $100 \mathrm{~g}_{\mathrm{COD}} \mathrm{m}^{-2} \mathrm{~d}^{-1}$ for municipal wastewater treatment [21]. On the other hand, the hydraulic loading rate (HLR) significantly differed from the usual values, due to different characterization of winery wastewater. Due to a very high organic load, the Cecchi CW WWTP worked, during the presented monitoring period, with a mean HLR of $0.05 \pm 0.02 \mathrm{~m}^{3} \mathrm{~m}^{-2} \mathrm{~d}^{-1}$ (range $0.02-0.10 \mathrm{~m}^{3} \mathrm{~m}^{-2} \mathrm{~d}^{-1}$ ). These values are one order of magnitude lower than the suggested ones for the design of FRB 1st stage for the treatment of municipal wastewater [21]. Consequently, the feeding scheme must be adapted to the different condition when FRB 1st stage is designed to serve wineries; in this case, the designers have opted for a shorter resting period $(6 \mathrm{~h})$ in comparison to the values used for municipal applications (usually seven days [21]). Therefore, the feeding and resting periods for FRB 1st are design variables to be properly addressed, especially for the design of CW WWTPs, which are expected to work under not common OLR and HLRs. At the same time, the optimal feeding scheme for an FRB 1st stage treating winery wastewater is still an open technical and scientific question deserving to be further studied in the near future.

The good performance of FRB 1st stage was fundamental for the proper functioning of the subsequent HF 2nd stage. Indeed, the high COD removal of the FRB 1st permitted to feed the HF 2nd stage with a mean cross-sectional organic loading rate of $279 \mathrm{~g}_{\mathrm{BOD} 5} \mathrm{~m}^{-2} \mathrm{~d}^{-1}$ (assuming a COD/BOD ratio of 2), in the range suggested by book and guidelines to avoid HF clogging, i.e., between $250 \mathrm{~g}_{\mathrm{BOD} 5}$ $\mathrm{m}^{-2} \mathrm{~d}^{-1}$ [22] and $500 \mathrm{~g}_{\text {BOD5 }} \mathrm{m}^{-2} \mathrm{~d}^{-1}$ [23]. Consequently, the HF 2 nd still not evidenced relevant clogging issues up to now, i.e., after 10 years of operation (excluding the pre-upgraded plant), confirming the suitability of HF CW technology in long-term recently evidenced by Vymazal [9].

Despite the good performance of HF 2nd stage, the FWS 3rd stage played an important role. Indeed, four of the 28 samples collected during the monitored period evidenced the need for the FWS 3rd stage to respect the limit for discharge in terms of COD. Only one time the system needed also the sand filter to make the effluent in agreement with the required water quality. The multistage $\mathrm{CW}$ WWTP of Cecchi winery performed with an overall mean COD removal efficiency of $97.5 \%$, confirming the importance to use multistage CWs for the treatment of high strength winery wastewater in case of stringent effluent targets, in agreement with Masi et al. [5].

The monitored data evidenced the suitability of the online sensor in catching the effluent COD patterns. This is giving practical help to the CW WWTP owner, which has an instrument to continuously monitor the performance and to manage the optional recirculation of FWS 3rd effluent toward the sand filter. In terms of full precision, the results cannot lead to general and definitive conclusions. The full 
precision was definitely good, with low mean error $(-17 \%)$ and with the majority of the error being less than $\pm 50 \%$. To maintain good performance, the CW WWTP owner follows a strict maintenance procedure. This confirms the need for strict protocol for the use in online sensors and to maintain the reliability of the sensor measurement, in agreement to what was evidenced by Papias et al. [17] for using online sensors to monitor nitrogen pollutants. On the other hand, the range of errors and the greater number of underestimations in comparison to overestimation seem to suggest to avoid a full substitution of manual sampling with an online sensor for the monitoring of the CW WWTP performance. Therefore, the possibility to reduce the operational and maintenance costs of CW WWTPs by substituting water quality samples expenditure with online monitor, as suggested by Garfí et al. [16], seems to be viable in case of CWs treating industrial wastewater, even though in several countries the related, more stringent water quality standards of the effluents (as in this case) will anyway require a minimum level of analysis with legal validity. The main advantages offered by the online and continuous data acquisition are linked to several opportunities, as for instance the design of smart CW WWTPs where sensors are couples to information technologies (ITs) that can be programmed for starting active aeration of the reactor, recirculation, prolonged or shortened HRTs, different HLRs, and so on. In terms of operation, the obtained results at Cecchi WWTP are very interesting because they demonstrate, by comparison with simultaneous samples analyzed in the laboratory, that sensors are able to properly identify the highest peaks and fluctuations of the substance concentrations. This kind of continuously updated information is extremely relevant for performance optimization, for understanding the behavior of the WWTP in different operative scenarios, and finally for driving the powering on or off of the eventual process enhancement tools. These conclusions need to be confirmed by a greater number of full-scale CW WWTPs equipped with online sensors and monitored, especially for the optimization of the maintenance protocol and the estimation of the confidence level of the instrument. The use of online sensors are hoped also to monitor interesting application of CWs other than wineries, as well as conventional municipal wastewater from medium-big scale $\mathrm{CW}$ WWTPs, but also to monitor the performance under other complex conditions, such as high hydraulic load variation (e.g., combined sewer overflow, or stormwater) or different industrial wastewater.

Author Contributions: A.R. elaborated the data, made the analyses, and wrote the manuscript; R.B. and N.M. were the designers of the WWTP, contacted the owner of the winery, and collected the data; F.M. was the Technical Director of the WWTP, and revised the manuscript from the point of view of both scientific validity (robustness of references and discussion) and English readability. All authors have read and agreed to the published version of the manuscript.

Funding: This research received no external funding.

Acknowledgments: We acknowledge the owner of the Cecchi and Sons winery and its staff (particularly Miria Bracali and Andrea Rossini), who shared the monitored data for this publication.

Conflicts of Interest: The authors declare no conflicts of interest.

\section{References}

1. Vymazal, J. Constructed wetlands for treatment of industrial wastewaters: A review. Ecol. Eng. 2014, 73, 724-751. [CrossRef]

2. Wu, S.; Wallace, S.; Brix, H.; Kuschk, P.; Kirui, W.K.; Masi, F.; Dong, R. Treatment of industrial effluents in constructed wetlands: Challenges, operational strategies and overall performance. Environ. Pollut. 2015, 201, 107-120. [CrossRef] [PubMed]

3. Sultana, M.Y.; Akratos, C.S.; Vayenas, D.V.; Pavlou, S. Constructed wetlands in the treatment of agro-industrial wastewater: A review. Hem. Ind. 2015, 69, 127-142. [CrossRef]

4. Stefanakis, A. Constructed Wetlands for Industrial Wastewater Treatment; John Wiley \& Sons Ltd.: Hoboken, NJ, USA, 2008; pp. 154-196.

5. Masi, F.; Rochereau, J.; Troesch, S.; Ruiz, I.; Soto, M. Wineries wastewater treatment by constructed wetlands: A review. Water Sci. Tech. 2015, 71, 1113-1127. [CrossRef] [PubMed] 
6. Masi, F.; Rizzo, A.; Bresciani, R. Treatment of Wineries and Breweries Effluents using Constructed Wetlands. In Constructed Wetlands for Industrial Wastewater Treatment; Stefanakis, A., Ed.; John Wiley \& Sons Ltd.: Hoboken, NJ, USA, 2018; pp. 95-104.

7. Marzo, A.; Milani, M. Winery wastewater, Chapter 4.11.5. In Wetland Technology: Practical Information on Design and Application of Treatment Wetlands; Langergraber, G., Dotro, G., Nivala, J., Rizzo, A., Stein, O., Eds.; IWA Publishing: London, UK, 2019; pp. 5-9.

8. Vymazal, J. Does clogging affect long-term removal of organics and suspended solids in gravel-based horizontal subsurface flow constructed wetlands? Chem. Eng. J. 2018, 331, 663-674. [CrossRef]

9. Paing, J.; Guilbert, A.; Gagnon, V.; Chazarenc, F. Effect of climate, wastewater composition, loading rates, system age and design on performances of French vertical flow constructed wetlands: A survey based on 169 full scale systems. Ecol. Eng. 2015, 80, 46-52. [CrossRef]

10. Morvannou, A.; Forquet, N.; Michel, S.; Troesch, S.; Molle, P. Treatment performances of French constructed wetlands: Results from a database collected over the last 30 years. Water Sci. Technol. 2015, 71, 1333-1339. [CrossRef] [PubMed]

11. Lavrnić, S.; Braschi, I.; Anconelli, S.; Blasioli, S.; Solimando, D.; Mannini, P.; Toscano, A. Long-term monitoring of a surface flow constructed wetland treating agricultural drainage water in Northern Italy. Water 2018, 10, 644. [CrossRef]

12. Masi, F.; Martinuzzi, N. Tolerance to hydraulic and organic load fluctuations in constructed wetlands. Water Sci. Technol. 2007, 56, 39-48. [CrossRef] [PubMed]

13. Rizzo, A.; Langergraber, G.; Galvão, A.; Boano, F.; Revelli, R.; Ridolfi, L. Modelling the response of laboratory horizontal flow constructed wetlands to unsteady organic loads with HYDRUS-CWM1. Ecol. Eng. 2014, 68, 209-213. [CrossRef]

14. Rizzo, A.; Langergraber, G. Novel insights on the response of horizontal flow constructed wetlands to sudden changes of influent organic load: A modeling study. Ecol. Eng. 2016, 93, 242-249. [CrossRef]

15. Boano, F.; Rizzo, A.; Samsó, R.; García, J.; Revelli, R.; Ridolfi, L. Changes in bacteria composition and efficiency of constructed wetlands under sustained overloads: A modeling experiment. Sci. Total Environ. 2018, 612, 1480-1487. [CrossRef] [PubMed]

16. Garfí, M.; Pedescoll, A.; Carretero, J.; Puigagut, J.; García, J. Reliability and economic feasibility of online monitoring of constructed wetlands performance. Desal. Water Treat. 2014, 52, 5848-5855. [CrossRef]

17. Papias, S.; Masson, M.; Pelletant, S.; Prost-Boucle, S.; Boutin, C. In situ continuous monitoring of nitrogen with ion-selective electrodes in a constructed wetland receiving treated wastewater: An operating protocol to obtain reliable data. Water Sci. Technol. 2018, 77, 1706-1713. [CrossRef] [PubMed]

18. Corbella, C.; Hartl, M.; Fernandez-Gatell, M.; Puigagut, J. MFC-based biosensor for domestic wastewater COD assessment in constructed wetlands. Sci. Total Environ. 2019, 660, 218-226. [CrossRef] [PubMed]

19. Molle, P.; Liénard, A.; Boutin, C.; Merlin, G.; Iwema, A. How to treat raw sewage with constructed wetlands: An overview of the French systems. Water Sci. Technol. 2005, 51, 11-21. [CrossRef] [PubMed]

20. APHA; AWWA; WEF. Standard Methods for the Examination of Water and Wastewater, 21st ed.; American Public Health Association: Washington, DC, USA, 2005.

21. Dotro, G.; Langergraber, G.; Molle, P.; Nivala, J.; Puigagut, J.; Stein, O.; Von Sperling, M. Treatment Wetlands; IWA Publishing: London, UK, 2017.

22. Kadlec, R.H.; Wallace, S. Treatment Wetlands, 2nd ed.; CRC Press: Boca Raton, FL, USA, 2009.

23. Constructed Wetlands Treatment of Municipal Wastewaters; EPA-625/R-99-010; US Environmental Protection Agency: Washington, DC, USA, 2000.

(C) 2020 by the authors. Licensee MDPI, Basel, Switzerland. This article is an open access article distributed under the terms and conditions of the Creative Commons Attribution (CC BY) license (http://creativecommons.org/licenses/by/4.0/). 